Perisai, Vol 5 (2), October 2021, 164-169

ISSN 2503-3077 (Online)

Journal

Homepage:https://journal.umsida.ac.id/index.php/perisaiDOI

Link: http://doi.org/10.21070/perisai.v5i2.1322

Article DOI: 10.21070/perisai.v5i2.1322

Original Research Article

\title{
Book Leverage in Islamic Banking in Indonesia
} Book Leverage pada Perbankan Syariah di Indonesia

\author{
Intan Shaferi ${ }^{1}$, Julia Safitri ${ }^{2}$, Arinal Rahmati ${ }^{3}$ \\ ${ }^{1}$ Fakultas Eknomika dan Bisnis, Universitas Jenderal Soedirman, ${ }^{2}$ Fakultas Ekonomi UniversitasTerbuka, \\ ${ }^{3}$ Sekolah Tinggi Ilmu Syariah (STIS) Ummul Ayman, Pidie Jaya
}

*Corresponding author. Email: intan.shaferi@unsoed.ac.id

Article history: Recieved Mei 9, 2021; Accepted July 2, 2021; Published October 8, 2021

HOW TO CITE: Intan Shaferi, Julia Safitri, Arinal Rahmati (2021) Book Leverage pada Perbankan Syariah di Indonesia (Book Leverage in Islamic Banking in Indonesia), Vol 5 (2), October 2021, 164-169. DOI Link: http://doi.org/10.21070/perisai.v5i2.1322

\begin{abstract}
The purpose of this study is to analyze the book leverage of Islamic banks in Indonesia. Book leverage shows how debt is used in Islamic banking. This study will provide results on how lag leverage, profitability and firm size as control variables have an effect on book leverage of Islamic banking in Indonesia.

This study uses data on Islamic banking in Indonesia with a five-year research period, 2016-2020. The study used secondary data from Islamic banking and analyzed using panel data regression. The results show that there is an influence between lag leverage, profitability, and firm size on book leverage of Islamic banking in Indonesia.
\end{abstract}

Keywords: Leverage, Profitabilitas, Ukuran Bank, Bank Syariah.

\begin{abstract}
ABSTRAK
Tujuan dari penelitian ini untuk menganalisa tentang book leverage pada bank syariah di Indonesia. Book leverage memperlihatkan bagaimana penggunaan hutang pada perbankan syariah. Penelitian ini akan memberikan hasil bagaimana lag leverage, profitabilitas dan ukuran perusahaan sebagai variabel kontrol memberikan efek pada book leverage perbankan syariah di Indonesia.

Penelitian ini menggunakan data perbankan syariah di Indonesia dengan periode penelitian selama lima tahun yaitu 2016-2020. Penelitian menggunakan data sekunder perbankan syariah dan dianalisis dengan menggunakan regresi data panel. Hasil penelitian memperlihatkan bahwa ada pengaruh antara lag leverage, profitabilitas, dan ukuran perusahaan pada book leverage perbankan syariah di Indonesia.
\end{abstract}

Kata kunci: Leverage, Profitabilitas, Ukuran Bank, Bank Syariah.

*Corespondent e-mail address intan.shaferi@unsoed.ac.id

Peer reviewed under reponsibility of Universitas Muhammadiyah Sidoarjo.

(C) 2021 Universitas Muhammadiyah Sidoarjo, All right reserved, This is an open access article under the CC

BY license (http://creativecommons.org/licenses/by/4.0/) 


\section{PENDAHULUAN}

Struktur modal menjadi landasan bagi banyak penelitian untuk keuangan perusahaan karena struktur modal memberikan banyak kontribusi bagi praktis perusahaan. Namun demikian, para akdemisi juga mendapatkan banyak hasil penelitian yang menarik ketika membahas struktur modal dari berbagai sudut pandang sektor. Salah satu yang cukup berkembang di Indonesia yaitu perbankan syariah.

Penelitian ini membahas bagaimana leverage pada perusahaan syariah mengalami perubahan dan berdampak pada struktur modal perusahaan. Struktur modal yang optimal telah menjadi landasan penelitian akademis di bidang keuangan perusahaan sejak Modigliani dan Miller (1958, 1963). Perusahaan memiliki karakteristik masing- masing sesuai bidang usaha maupun industrinya. Seperti halnya pada perbankan syariah yang memberikan sentuhan berbeda pada karakteristik keuangan karena secara prinsip- prinsip syariah memang berbeda dengan perusahaan secara konvensional. Oleh karena itu penelitian ini memfokuskan pada perbankan syariah.

Perbankan syariah menyajikan sistem keuangan perbankan syariah berdasarkan hukum dagang, dimana terdapat kesetaraan dalam keadilan sosial, kejujuran transaksi bisnis, kewirausahaan, pengamanan hak, keterbukaan dan pengkhianatan sesuai dengan hukum Islam dan apa yang disampaikan oleh Nabi Muhammad SAW (Salman \& Nawaz, 2018). Oleh karena itu perbankan syariah memiliki karakteristik tersendiri dengan berdasarkan ketentuan-ketentuan dalam Islam.

Banyak penelitian yang mengangkat perbankan syariah baik di dalam maupun luar negeri menunjukan bahwa perbankan syariah mengalami perkembangan yang cukup signifikan dalam jumlah nasabah maupun dalam peningkatan jumlah bank. Dengan perkembangan yang luar biasa, bukan berarti perbankan syariah tidak memiliki keragaman dan karakteristik dalam struktur modal. Oleh karena itu penelitian ini mengangkat leverage yang dalam struktur modal memperlihatkan bagaimana posisi utang perusahaan. Leverage yang digunakan dalam penelitian yaitu book leverage, dimana beberapa penelitian telah menggunakan pendekatan ini untuk mengukur leverage.

Pada penelitian ini, beberapa faktor dikaitkan dengan book leverage seperti lag leverage, profitabilitas dan ukuran perusahaan. Variable tersebut digunakan dalam penelitian dengan mempertimbangkan pada sektor pebankan syariah. Lag leverage memperlihatkan bagaimana kondisi leverage pada periode sebelumnya, hal ini memerlihatkan relevansi bahwa dampak yang ditimbulkan atas leverage periode saat ini cukup erat dengan kondisi leverage pada periode sebelumnya.

Selain itu profitabilitas memberikan arah tersendiri pada leverage, dimana pada trade off theory profitablitas memiliki pengaruh positif atas leverage, sedangkan pada packing order theory memberikan arah berlawanan. Profitabilitas pada perusahaan menjadi faktor yang memiliki kekuatan tersendiri mengingat orientasi perusahaan untuk menghasilkan keuntungan. Namun demikian, penggunaan leverage tentu memiliki alasan berbeda mengingatkebutuhan akan modal perusahaan cukup berbeda-beda.

Ukuran perusahaan juga merupakan faktor yang memberikan indikasi bagaimana kebijakan struktur modal yang diterapkan perusahaan. Hal ini tentu memberikan gambaran tersendiri pada perbankan, mengingat aturanaturan yang melekat pada perbankan secara umum. Namun demikian, penelitian-penelitian sebelumnya telah banyak membahas bagaimana kaitan ukuran perusahaan dan leverage dan masih memberikan hasil berbeda. Oleh karena itu ukuran perusahaan digunakan dalam penelitian ini dengan landasan bahwa hasil akan memberikan kontribusi berarti bahwa ukuran perusahaan akan cukup berpengaruh pada perbankan syariah di Indonesia, dimana Indonesia saat ini memiliki beberapa perbankan syariah yang cukup populardi masyarakat.

\section{TINJAUAN PUSTAKA}

Hukum perdagangan yang dikenal sebagai fiqh al- mu'alamat adalah dasar dari sistem keuangan Islam mempertimbangkan masalah keadilan sosial, kesetaraan dan kewajaran dalam semua transaksi bisnis, dan bertumpu pada promosi kewirausahaan, perlindungan hak milik, dan transparansi dan kesucian kewajiban kontrak. Berdasarkan aturan hukum Islam yang dikenal sebagai syariah, transaksi komersial diperbolehkan selama bebas dari kegiatan riba (bunga), gharar (ketidakpastian), maisir (perjudian), dan non-halal (dilarang). Beberapa hal terkait dasar-dasar tanggung jawab sosial dan etisnya, menarik bagi Muslim dan non-Muslim yang berusaha untuk berinvestasi dalam produk-produk yang bertanggung jawab secara social (Ariss, 2010).

Terdapat lima prinsip yang membedakan keuangan syariah atau syariah dari keuangan konvensional. Di satu sisi, ada larangan riba yang umumnya diartikan sebagai bunga atau bunga yang berlebihan, larangan gharar atau risiko atau ketidakpastian yang umumnya diartikan sebagai spekulasi, dan larangan pembiayaan untuk sektorsektor terlarang seperti senjata, obat-obatan, alkohol, dan babi. Di sisi lain, terdapat prinsip bagi hasil dan kerugian dan prinsip bahwa semua transaksi harus didukung oleh transaksi ekonomi riil yang melibatkan aset 
berwujud. Agar bank dan nasabah mematuhi syariah, selama beberapa dekade terakhir, produk khusus telah dikembangkan yang menghindari konsep bunga dan menyiratkan tingkat pembagian risiko tertentu. Salah satu fitur penting adalah melewati risiko antara deposan dan peminjam. Di antara produk perbankan Islam yang paling umum adalah pinjaman kemitraan antara bank dan peminjam, yang didasarkan pada pembagian keuntungankerugian. Berdasarkan kontrak mudharabah, keuntungan dibagi dengan rasio yang telah ditentukan, sedangkan kerugian ditanggung secara eksklusif oleh bank, yaitu pengusaha ditanggung oleh ketentuan kewajiban terbatas. Sementara wirausahawan memiliki kendali penuh atas bisnisnya, keputusan investasi utama, termasuk partisipasi investor lain, harus disetujui oleh bank. Kontrak musyarakah, sebaliknya, menjadikan bank sebagai salah satu dari beberapa investor, dengan keuntungan dan kerugian dibagi di antara semua investor. Pengaturan kemitraan ini dicerminkan di sisi simpanan, dengan rekening investasi atau simpanan yang tidak menyiratkan pengembalian tetap yang telah ditetapkan tetapi bagi hasil bagi kerugian. Deposito investasi semacam itu dapat dikaitkan dengan tingkat keuntungan bank atau ke akun investasi tertentu di sisi aset neraca bank. Deposan dengan demikian beralih dari kreditor bank ke penuntut sisa. Produk keuangan pengaduan syariah lainnya tidak didasarkan pada bagi hasil, seperti akad Murabahah, yang menyerupai akad leasing di perbankan konvensional. Dengan melibatkan pembelian barang, pihaknya menyiasati larangan untuk mengembalikan pinjaman uang. Seperti dalam kontrak leasing, bank membeli barang investasi atas nama klien dan kemudian menjualnya kepada klien, dengan pembayaran yang diatur secara bertahap dan margin keuntungan dalam bentuk fee. Demikian pula, sewa operasi (Ijarah) di mana bank menyimpan kepemilikan barang investasi dan menyewakannya kepada klien untuk mendapatkan bayaran adalah transaksi keuangan yang layak menurut hukum Syariah. Rekening investasi, akhirnya, seperti dibahas di atas, mencerminkan pinjaman kemitraan di sisi aset, dengan terlibat penuh dalam pengaturan pembagian untung-rugi-risiko bank-bank Islam. Jadi, dana tersebut berisi dana yang menjadi tanggung jawab langsung bank syariah serta dana yang mereka kelola atas nama investor. "(Beck, DemirgüçKunt, \& Merrouche, 2010)

Menurut International Association of Islamic Banks (IAIB) mendefinisikan Islamic banking sebagai Bank Islam pada dasarnya menerapkan konsep banking baru yang menganut secara ketat aturan Syariah Islam di bidang keuangan dan transaksi lainnya. Oleh karena itu, intinya jelas bahwa perbankan syariah membedakan dengan perbankan konvensional dalam hal misi dan tujuan serta tugasnya terhadap masyarakat. Bank Islam mengambil semua tugas dan tanggung jawab ini lebih besar dari bank konvensional, (Hassan \& Adnan, 1998). Perbankan konvensional pada dasarnya didasarkan pada hubungan debitur-kreditur antara deposan dan bank di satu sisi dan antara peminjam dan bank di sisi lain, dengan bunga sebagai harga kredit, yang mencerminkan biaya peluang uang. Bashir (2000) meneliti kinerja Bank Islam di kawasan Timur Tengah antara 1993 dan 1998 (Ramlan \& Adnan, 2016). Perbankan syariah mengacu pada praktik-praktik yang sesuai dengan Syariah, di mana larangan yang umum diakui meliputi: pembayaran bunga utang, produk turunan yang kompleks, short-selling, perjudian, dan berurusan dengan alkohol dan tembakau. Keuangan Islam terlibat dengan layanan berbasis ekuitas (Mudarabah) di mana seorang investor dan pengusaha memasuki usaha bagi hasil bersama. Murabahah adalah penjualan biaya-plus-keuntungan. Dengan Ijarah, bank menyewa aset yang mengenakan biaya set (Izzeldin, Johnes, Ongena, Pappas, \& Tsionas, 2020).

Para pendukung teori trade-off berpendapat bahwa perusahaan yang lebih besar cenderung lebih terdiversifikasi dan kurang rentan terhadap kebangkrutan. Jadi ukuran perusahaan, proksi terbalik untuk probabilitas kebangkrutan, harus berhubungan positif dengan penawaran hutang (Sheikh Nadeem \& Qureshi Muhammad, 2017).

\section{METODOLOGI}

Penelitian ini merupakan penelitian kuantitatif dengan menggunakan sumber data sekunder. Sampel yang dgunakan dalam penelitian ini yaitu bank syariah yang ada di Indonesia yaitu Bank Mandiri Syariah, Bank BNI Syariah, Bank Muamalat, Bank Mega Syariah, dan Bank BRI Syariah. Periode penelitian yaitu empat tahun dari tahun 2016-2020. Pemilihan bank ini berdasarkan data lima tahun terakhir yang dibutuhkan dalam penelitian.

Penelitian menggunakan regresi dengan variabel book leverage sebagai variabel dependen. Variabel independen penelitian yaitu lag leverage, profitablitas dan ukuran perusahaan sebagai variabel kontrol.

Variabel book leverage menggunakan pengukuran sebagai berikut:

(Short Term Debt + Long Term Debt)

Book Leverage $\quad=$

Total Assets 
Book leverage adalah rasio hutang yang digunakan untuk mengukur rasio antara total hutang dan total aset. Dengan kata lain, bagaimana banyak aset perusahaan dibiayai oleh hutang atau berapa banyak hutang perusahaan mempengaruhi pengelolaan asset.

Variabel independen yaitu lag book leverage, dimana pengukuran menggunakan Book Leverage t-1. Selain lag book leverage, variabel lain yang digunakan yaitu p rofitabilitas. Dimana proftabilitas menggunkan pengukuran operating income before depreciation dibagi total assets. Variabel kontrol yang digunakan yaitu ukuran perusahaan dengan pengukuran natural log total assets.

Penelitian dilakukan dengan menggunakan regresi dengan persamaan sebagai berikut:

Book Leverage $=\beta_{0}+\beta_{1}$ Lag Leverage $+\beta_{2}$ Profitablity $+\beta_{3}$ Size $+\varepsilon_{i t}$

Dimana Book Leverage merupakan capital structure perusahaan, dengan lag leverage merupakan leverage pada periode sebelumnya, profitability yaitu profitabilitas perusahaan pada tahun ke $\mathrm{t}$, dan size merupakan ukuran perusahaan.

\section{HASIL DAN PEMBAHASAN}

Bank syariah memiliki karakteristik tersendiri dibandingkan bank konvensional. Dengan prinsip-prinsip Islam sebagai landasan utama maka bank Islam beroperasi dengan berbagai ketentuan yang berlaku. Bank syariah juga memiliki beberapa kekuatan dan kelebihan yang membuat pasar untuk bank syariah semakin luas. Perbankan syariah di Indonesia cukup berkembang, selain karena mayoritas penduduknya yang beragama Islam, perkembangan juga ditopang dengan banyaknya pengetahuan mengenai perbankan syariah. Sehingga bank syariah banyak diminati.

Penelitian ini mengangkat leverage pada bank syariah. Karena leverage merupakan pengungkit, dimana terkait struktur modal, maka peneltian ini ingin memberikan kontribusi bahwa leverage periode sebelumnya memberikan pengaruh pada leverage saat ini. Selain itu profitabilitas juga merupakan faktor yang mempengaruhi leverage. Selain itu ukuran perusahaan dilihat sebagai kontrol variabel, yang memberikan kontribusi besar tidaknya leverage pada perusahaan.

Hasil analisis yang dilakukan dalam penelitian disajikansebagai berikut.

TABLE 1 Hasil Analisis

\begin{tabular}{|c|c|c|c|c|c|}
\hline \multirow{2}{*}{\multicolumn{2}{|c|}{ SUMMARY OUTPUT }} & \\
\hline & & & & & \\
\hline \multicolumn{6}{|c|}{ Regression Statistics } \\
\hline Multiple R & 0,988873248 & & & & \\
\hline R Square & 0,987547965 & & & & \\
\hline $\begin{array}{l}\text { Adjusted R } \\
\text { Square }\end{array}$ & 0,986903451 & & & & \\
\hline $\begin{array}{l}\text { Standard } \\
\text { Error }\end{array}$ & 0,017781045 & & & & \\
\hline Observations & $\underline{12}$ & & & & \\
\hline \multicolumn{6}{|l|}{ ANOVA } \\
\hline & $d f$ & $S S$ & $M S$ & $F$ & $\begin{array}{c}\text { Significance } \\
F\end{array}$ \\
\hline Regression & 3 & 1,120598858 & 0,373533 & 118,447 & 0,00000 \\
\hline Residual & 8 & 0,002529324 & 0,000316 & & \\
\hline \multirow[t]{2}{*}{ Total } & 11 & 1,123128182 & & & \\
\hline & Coefficients & $\begin{array}{c}\text { Standard } \\
\text { Error }\end{array}$ & $\underline{t \text { Stat }}$ & $\underline{P \text {-value }}$ & \\
\hline Intercept & 0,054170104 & 0,231580614 & 0,233915 & 0,820926 & \\
\hline
\end{tabular}




\begin{tabular}{|l|c|c|c|c|c|}
$\begin{array}{l}\text { Lag } \\
\text { Leverage }\end{array}$ & 1,101480918 & 0,223279969 & 3,59152 & 0,084652 & \\
\cline { 1 - 5 } Profitability & 2,907076818 & 1,184400948 & 2,45447 & 0,039659 & \\
\cline { 1 - 5 } Size & $\underline{0,004235055}$ & $\underline{0,013061694}$ & $\underline{-0,32423}$ & $\underline{0,754075}$ & \\
\hline
\end{tabular}

Persamaan hasil regresi yaitu:

Book leverage $=0,054+1,015$ Lag Leverage $+2,907$ Profitability $-0,004$ Size + e

Hasil regresi menunjukan R Square sebesar 98 persen yang berarti bahwa lag leverage, profitabilitas, dan ukuran perusahaan berpengaruh terhadap book leverage sebesar $98 \%$ dan sisanya dipengaruhi variabel lain yang tidak termasuk dalam penelitian. Hasil koefisien regresi untuk lag leverage sebesar 1,015 yang berarti bahwa 1 perubahan pada lag leverage memberikan efek 1,015 kali pada book leverage. Koefisien regresi dari profitabilitas sebesar 2,907 memberikan makna bahwa 1 perubahan pada profitabliitas menyebabkan perubahan sebesar 2,907 pada book leverage.

Hasil untuk variabel independen terhadap dependen menyatakan pengaruh signifikan. Dengan demikian bahwa lag leverage memiliki pengaruh signifikan terhadap book leverage mendukung penelitian sebelumnya (Alnori \& Alqahtani, 2019). Hal ini menandakan bahwa bagaimana kebijakan struktur modal yang pada periode sebelumnya berpengaruh terhadap kondisi leverage perusahaan pada periode tertentu. Variabel lain yaitu profitabilitas dengan

hasil menunjukan pengaruh signifkan terhadap book leverage. Hasil ini mendukung penelitian sebelumnya (Alnori \& Alqahtani, 2019). Hal ini menunjukan dukungan pada trade off theory. Variabel lain yaitu size yang merupakan ukuran perusahaan. Dimana hasil penelitian menunjukan bahwa size tidak berpengaruh pada leverage. Hal ini tidak mendukung dari penelitian sebelumnya (Alnori \& Alqahtani, 2019; Sheikh Nadeem \& Qureshi Muhammad,2017).

Hasil statistik tersebut memperlihatkan bahwa bank syariah dalam kurun waktu penelitian memperlihatkan adanya penggunaan leverage pada struktur modalnya. Namun demikian perlu dipertimbangkan bahwa perbankan memiliki peraturan tersendiri terhadap kesehatan keuanganya. Hal tersebut dapat memberikan dampak pada penggunaan leverage. Namun demikian, bahwa bank syariah memiliki beberapa prinsip-prinsip Islam maka pengaturan keuangan juga berlandaskan hal tersebut.

\section{KESIMPULAN}

Hasil penelitian memperlihatkan bahwa book leverage dipengaruhi oleh lag leverage dan profitabilitas. Hal ini memperlihatkan bahwa kondisi perbankan syariah di Indonesia dari period ke periode memiliki keterkaitan yang kuat. Leverage yang dimiliki memiliki pengaruh pada kebijakan. Namun demikian hasil meunjukan bahwa size tidak memiliki pengaruh artinya bahwa kebutuhan terhadap leverage tidak mengenal batasan pada ukuran perbankan.

Penelitian selanjutnya diharapkan bahwa penelitian menambahkan variabel bebas yang menjadi faktor untuk melihat pengaruhnya pada leverage perbankan syariah. Selain itu, jumlah sampel juga dapat ditambahkan dengan menambahkan variabel mediasi yang memberikan pengaruh pada leverage perbankan syariah di Indonesia.

\section{DAFTAR PUSTAKA}

Alnori, F., \& Alqahtani, F. (2019). Capital structure and speed of adjustment in non-financial firms: Does sharia compliance matter? Evidence from Saudi Arabia. Emerging Markets Review, 39, 50-67. doi:https://doi.org/10.1016/j.ememar.2019.03.008

Ariss, R. T. (2010). Competitive conditions in Islamic and conventional banking: A global perspective. Review of FinancialEconomics, 19(3), 101-108.

Beck, T., Demirgüç-Kunt, A., \& Merrouche, O. (2010). Islamic vs. conventional banking: Business model, efficiency and stability: The World Bank.

Izzeldin, M., Johnes, J., Ongena, S., Pappas, V., \& Tsionas, M. (2020). Efficiency convergence in Islamic and conventionalbanks. Swiss Finance Institute Research Paper(19-71). 
Ramlan, H., \& Adnan, M. S. (2016). The profitability of Islamic and conventional bank: Case study in Malaysia. Procedia Economics and Finance, 35, 359-367.

Salman, A., \& Nawaz, H. (2018). Islamic financial system and conventional banking: A comparison. Arab economic and business journal, 13(2), 155-167.

Sheikh Nadeem, A., \& Qureshi Muhammad, A. (2017). Determinants of capital structure of Islamic and conventional commercial banks: Evidence from Pakistan. International Journal of Islamic and Middle Eastern Finance and Management, 10(1), 24-41. doi:10.1108/IMEFM-10-2015-0119

Conflict of Interest Statement: The authors declare that the research was conducted in the absence of any commercial or financial relationships that could be construed as a potential conflict ofinterest.

Copyright (C) tahun terbit nama belakang and nama belakang. This is an open-access article distributed under the terms of the Creative Commons Attribution License (CC BY). The use, distribution or reproduction in other forums is permitted, provided the original author(s) and the copyright owner(s) are creditedandthatthe originalpubli-cationin this journal is cited, inaccordance with accepted academic practice. No use, distribution or reproduction is permitted which does not complywith these terms. 